\title{
Religieë van mense en die verlossende kennis van God
}

D Crafford

Emeritus professor: Departement Godsdiens en Sendingwetenskap

Universiteit van Pretoria

\section{ABSTRACT}

\section{Human religions and the saving knowledge of God}

It has become an accepted practice to speak of the relationship of Christianity to other religions in terms of exclusivism, inclusivism and pluralism. These categories are actually not very helpful. The emphasis must not be on the question of excluding or including people from salvation but rather on a saving knowledge of God. Human religions have a limited or distorted knowledge of the supreme Reality. It is only through selfrevelation of God that a true saving knowledge of the ultimate Reality can be attained. This happens through the self-revelation of God in Scripture and especially in the incarnation and saving acts of God in Christ and through the enlightening work of the Holy Spirit.

Die tradisionele siening dat verlossing slegs moontlik is binne die kerk of dan ten minste slegs deur geloof in Jesus Christus as enigste Verlosser van die mensheid, het in die jongste tyd sterk in gedrang gekom. Dialoog en meer kontak met nie-christelike religieë het hierin 'n rol gespeel. Die bestaan van ' $n$ gemeenskaplike geloof in 'n misterieuse realiteit (immanent of transendent) wat die menslike bestaan oral en altyd sou beïnvloed, het gelei tot 'n gelykskakeling van alle religieë. Gevolglik is aanvaar dat enige geloof in 'n misterieuse realiteit wat tot 'n verantwoordelike en verhewe lewenswyse lei, vir die aanhangers van die betrokke religie 'n verlossingsweg word. Dit is die standpunt van die pluralisme'. Alle religieë open die weg tot verlossing vir die getroue aanhangers daarvan. Volgens hierdie standpunt is daar dus geen teenstelling tussen die religieë van mense en die verlossende kennis van God of van 'n transendente Realiteit nie.

Hierdie artikel wil op teologiese gronde die stelling verdedig dat daar 'n skerp kontras is tussen die religeë van mense en die verlossende kennis van God wat die gevolg is van sy self-openbaring.

In wese kom dit dus neer op die vraag van hoe die christelike belydenis van die inkarnasie van God in Jesus Christus, soos bevestig deur die getuienis van die apostels en soos dit neerslag gevind het onder leiding van die Heilige Gees, in verband gebring kon word met die bestaan van talle 
religieë? Of anders gestel: kan menslike religieë, wat deel is van menslike pluraliteit as werklikheid, werklik mense uitsluit van 'n verlossende kennis van God? Is dit nie in stryd met die belydenis dat God die Skepper is van alle nasies (met hulle kulture en religieë) wat hulle liefhet en begeer dat hulle nie verlore sal gaan nie, maar gered sal word? In kort kom dit daarop neer: wat is die verband tussen God se universele heilswil en sy partikulêre heilsdaad in Jesus Christus?

Die vraag of verlossing in ander religieë moontlik is, het drie soorte reaksies uitgelok naamlik dié van eksklusivisme, inklusivisme en pluralisme ${ }^{2}$.

Die standpunt van eksklusivisme is dat verlossing slegs deur Jesus Christus plaasvind en dan wel deur doelbewuste geloof en bekering. Ander religieë word gesien as dwalinge van mense wat in opstand teen God is ${ }^{3}$.

Volgens die standpunt van inklusivisme is God se reddende genade teenwoordig in ander religieë. Dit geskied egter op grond van die kosmiese en universele betekenis van Christus se verlossingswerk. Waar mense in ander godsdienste gered word op grond van hulle strewe na die goeie, geskied dit deur die verlossingswerk van Christus, al is hulle nie bewus daarvan nie ${ }^{4}$.

Die standpunt wat die mees radikale breuk met tradisionele christelike standpunte verteenwoordig, is pluralisme wat leer dat enige godsdiens met ' $n$ bewussyn van ' $n$ misterieuse realiteit tot verlossing kan lei. Daar is immers talle geldige weë om by die absolute realiteit uit te kom $^{5}$. Volgens dié standpunt moet daar afgesien word van Christus as unieke verlosser.

Bogenoemde beskrywings van die drie betrokke standpunte is in meer as een opsig onbevredigend en behoort nie meer as beskrywende paradigmas gebruik te word nie.

Die term eksklusivisties is onbruikbaar omdat dit die indruk skep dat sommige mense by voorbaat van God se heil uitgesluit is. Dit sou slegs bruikbaar wees binne ' $n$ radikale uitverkiesingsleer wat die heil slegs toesê aan die uitverkorenes en al die ander uitsluit. God se heilsbedoelinge moet egter aan alle mense verkondig word as 'n ope uitnodiging tot geloof. Die Skrif verkondig duidelik die universele heilswil van God. Christus se sterwe is genoegsaam vir alle mense. God wil dat alle mense tot die kennis van die waarheid kom (1 Tim 2:4 en 2 Pet 3:9). Hy begeer nie die dood van die sondaar nie, maar dat hy hom sal bekeer en lewe (Eseg 18:23,32). God stel juis in sy lankmoedigheid die wederkoms uit omdat Hy nie wil hê dat iemand verlore gaan nie, maar dat almal hulle moet bekeer (2 Pet 3:9). Dit is duidelik dat God se partikuliere bemoeienis met Israel en sy heilsdaad in Jesus Christus op die universele heil van al die nasies gerig is. 
Die term eksklusivisme maak nie genoegsaam ruimte vir God se genadewerking ook buite die Christendom nie. Dit lê God se vrye heilsbeslissing aan bande asof Hy nie ook buitengewone genade kan bewys aan mense buite die christelike tradisie nie. Die Ou Testament toon hoedat God besig was met mense soos Melgisedek, Jetro, Beleam en Ragab buite die verbond met Israel om ${ }^{6}$. Eksklusivisme impliseer by voorbaat die valsheid van ander religieë en verklaar hulle aanhangers as verlore, terwyl God juis die religieë van mense ook ten goede kan gebruik en wil dat sy heil aan almal verkondig moet word.

Die term inklusivisme is onbruikbaar omdat dit die indruk skep dat alle mense voor die voet gered sal word al is dit dan deur die universele verlossingswerk van Christus. Dit neem nie in ag dat mense die heilsboodskap moet hoor en aanneem deur 'n positiewe geloofsbeslissing nie. Om 'n goeie gewete, tekens van geloof en goeie dade by ander religieë aan die verlossende genade van Christus toe te skryf, gaan te ver. Dit kan doodgewoon toegeskryf word aan God se algemene genade wat onder alle mense werksaam is ${ }^{7}$. Om mense, soos Karl Rahner dit doen, tot anonieme Christene te verklaar sonder dat hulle dit self wil wees, is niks minder as paternalistiese en hooghartige optrede nie. Die kosmiese en universele betekenis van Christus se heilswerk mag nie misgekyk word nie, maar nêrens in die Skrif kry ons 'n aanduiding dat dit lei tot universele verlossing nie. Die dringende eis dat God se heil verkondig en aan almal bekendgemaak moet word, spreek die teendeel. Die groot fout van die inklusivisme is dat dit die totale verdorwenheid van die menslike geslag ná die sondeval nie genoegsaam in ag neem nie.

Pluralisme gaan van die standpunt uit dat alle religieë met dieselfde misterieuse realiteit te doen het en dus in wese gelyk is. Dit is egter 'n gelykskakeling van dinge wat nie gelyk wil wees nie. Elke religie het 'n eie partikularisme - 'n eie struktuur en verstaan van die misterieuse ${ }^{8}$. Elkeen glo dat sy verstaan van die werklikheid beter is as die van die ander. Die verskillende religieë verstaan hulleself nie as gelyk aan mekaar nie, maar word deur die pluraliste gelyk verklaar. Teologies is die standpunt van die pluralisme totaal nie aanvaarbaar nie ${ }^{9}$. Dit gebruik 'n hermeneutiek wat alle tekste, wat van die goddelikheid en pre-eksistensie van Christus getuig, tot mitologie en metaforiese spreke verklaar. Die Bybel dien die heilsgebeure rondom Christus egter omonwonde as historiese gebeure aan en nie as mitologiese gebeure nie. Trouens, die Christendom as godsdiens is gebou op die inkarnasie van God as historiese gebeurtenis. So is dit oor twee duisend jaar in kerklike belydenisse bely. Dit is dus aanmatigend van pluraliste om nou skielik 'n weg van relativisme as die enigste aanvaarbare 
weg te wil voorhou en die tradisionele christelike belydenisse as naïef te wil verklaar.

Die probleem van die pluralisme is dat dit verlossing losmaak van die kennis van die transdendente werklikheid. Hulle uitgangspunt is juis dat die naam van die godheid onnoembaar en sy wese onkenbaar is. John Hick werk met die Neo-Kantiaanse onderskeiding van "the - Real - in - itself" en "the Real - as - humanly - thought - and - experienced"10. Dit beteken dat die Realiteit an sich geen attribute het nie en dus onnoembaar, vormloos en leeg is. Wanneer mense egter aan Hom dink, gee hulle aan Hom 'n bepaalde vorm soos Adonai, die Drie-eenheid, Allah, die Brahman, Tao, ensovoorts. Die fenomenologiese manifestasies van die misterieuse realiteit is dus nie die realiteit self nie.

Met hierdie uitgangspunt ontken die pluralisme natuurlik kategories enige moontlikheid van self-openbaring van die godheid. Die aansprake van Judaïsme, Islam en Christendom dat God Hom op 'n besondere wyse openbaar het, word nie werklik ernstig geneem nie. Volgens hulle is elke bewussyn van die transendente realiteit immers die resultaat van mense se gedagtes en ervaringe. Daar bestaan dus slegs subjektiewe kennis en ervaring van die realiteit en geen objektiewe kennis wat op openbaring berus nie.

Hierdie standpunt is direk in stryd met die Skrif wat duidelik bely dat daar tyd van onkunde was (Hand 17:30), maar dat God Homself in die volheid van die tyd (Gal 4:4) openbaar het in Christus. Die geheimenis wat oor al die eeue onkenbaar was, is openbaar gemaak (Ef $1: 9 ; 3: 3-5 ; 6: 19$; Rom 16:25-26). Die sluier waarmee die volke bedek was en die omhulsel waarin die nasies toegevou was, is weggeneem (Jes 25:7).

God het deur Christus die wêreld met homself versoen (2 Kor 5:19). Hierdie Christus is bely as pre-eksistente God deur wie alles tot stand gekom het (Joh 1:2) en Hy sal ook die eskatologiese regter wees wat sal oordeel oor alle mense (Hand 17:31, Joh 5:27). Paulus self verstaan die boodskap wat hy verkondig nie as mensewoorde nie, maar as die woord van God (1 Tess 2:13). Hy beroep hom op 'n direkte openbaring wat van Jesus Christus kom (Gal 1:10-12; Hand 22:17). Waar God Homself vroeër deur die profete geopenbaar het, het hy nou die finale woord gespreek deur sy Seun wat "die ewebeeld van die wese van God is" (Heb 1:1-2). Hierdie geopenbaarde waarheid moes aan die hele wêreld verkondig word (Rom 16:26).

Hick soek die gemene faktor van alle religieë in die feit dat hulle mense oproep om van self-gesentreerdheid na realiteit-gesentreerdheid te beweeg. Die grond van religieuse ervaringe is die werklikheid van 'n 
transendente realiteit wat op mense inwerk. Die manier waarop mense hierop reageer is hulle eie vormgewing an die realiteit. Die waarheid van 'n religie word egter bepaal deur die realiteit - gesentreerdheid van sy aanhangers. Dit maak nie saak watter vorm aan hierdie realiteit gegee is nie. Hierdie standpunt is nie sonder probleme nie. Daar is religieuse strominge, veral in die Boeddhisme, wat 'n transendente Realiteit ontken en mense juis oproep tot self - gesentreerdheid. Behalwe dit, sal meeste religieë nie die toets van hierdie norm slaag nie. Die mens is in wese selfsugtig en selfgesentreerd. Dit is die gevolg van die sonde. Die meeste aanhangers van alle religieë leef dus nie werklik God-gesentreerd nie. Selfs in die Christendom sou weinig werklik hiervoor kwalifiseer. As dit die norm vir die verlossing van mense word, is die wat gered word inderdaad min. So gesien, word die religieë nie almal verlossingsweë nie, maar openbaar hulle juis die mens se onvermoë om homself te red. Die mens kan ten spyte van al sy soeke nie werklik by God uitkom nie. Daarom was dit nodig vir God om in die inkarnasie na die mens uit te reik.

Die oplossing van die Skrif vir hierdie dilemma is om telkens te wys hoedat God van sy kant af die sondaar opsoek. Hy bemoei Hom met die mens in sy verlorenheid. Hy wys vir hom die weg van geloof aan as die enigste manier om God te ken en by Hom uit te kom (Rom 5:1). In werklikheid is daar slegs een wat werklik God-gesentreerd kon lewe, en dit is Jesus Christus, in wie die volheid van God gewoon het (Kol 2:9). Alleen deur geloof in Christus en deur die misterie van die werking van die Heilige Gees kan mense werklik God-gesentreerd lewe.

Indien eksklusivisme, inklusivisme en pluralisme dan nie vir ons 'n bevredigende antwoord bied nie, hoe moet ons dan die verhouding van menslike religieë tot die verlossingswerk van Christus sien?

Om op hierdie vraag te antwoord, sal ons eers moet bepaal wat religie is. Religie is daardie bewussyn en aanvaarding van 'n misterieuse transendente dimensie of werklikheid wat die mens se bestaan kan beïnvloed en waarmee hy in 'n bepaalde verhouding moet staan ten einde die hoogste goed te kan bereik en sin in die lewe te ervaar ${ }^{11}$. Dit is 'n primêre ingesteldheid tot die lewe wat eie aan die mens is. Dit is die element wat die mens mak tot homo religiosus - 'n wese wat sy eie posisie ten opsigte van homself, sy medemens, die skepping en die transendente werklikheid moet bepaal.

Ons kan dus volmondig met John Hick saamstem dat religie die gevolg is van die mens se bewussyn van 'n transendente werklikheid en dus 'n unieke deel van menswees vorm. Dit is trouens ook die standpunt van Rudolf Otto ${ }^{12}$, Joachim Wach ${ }^{13}$, Mircia Eliade ${ }^{14}$, en E W Hopkins ${ }^{15}$. 
Dit kom ooreen met wat Calvyn 'n sensus diviniraris en semen religionis noem - 'n bewussyn van die goddelike wat by alle mense intuitief teenwoordig is. Dit is die grond waaruit religieuse denke en praktyke van alle mense ontspring. Teologies moet ons bely dat dit eenvoudig is soos God die mens geskep het. Die religieuse bewussyn van die mens maak dit vir God moontlik om in ' $n$ bepaalde verhouding tot Hom te staan. Met diere is so 'n verhouding nie moontlik nie. Die religieuse bewussyn skep die moontlikheid vir die mens om God se self-openbaring te kan ontvang en om tot kennis van God te kan kom.

John Hick is reg in soverre hy die religieuse bewussyn sien as die grond van alle religieuse denke en handelinge. Hy is egter verkeerd as hy dink dat dit die mens God-gesentreerd sou maak. Dit mak hom wel 'n soeker na God, maar as gevolg van die verblinding van die sonde kan hy nie werklik by God uitkom nie. Hy kan alleen 'n baie beperkte en meesal misvormde kennis van God langs die religieuse weg verkry. Dit kan hom allermins God-gesentreerd maak. In die meeste religië̈ staan die mens self of die natuur of geeste en afgode in die sentrum en nie die absolute singewer van die totale werklikheid nie.

Die religieuse bewussyn was bedoel om die mens in die regte verhouding met die Skeppergod te plaas. As gevolg van die sondeval is hy eksistensieel van God verwyder. Die teologiese begrip van 'n sondeval is natuurlik nie vir die filosowe wat pluralisme as teorie ontwerp het aanvaarbaar nie. Daarom kyk hulle die effek van die verduisterende werking van die sonde op religie mis en werk met 'n optimistiese mensbeskouing.

Volgens Calvyn het die sondeval die natuurlike gawes van verstand, oordeelsvermoë en wil van die mens aangetas, maar nie vernietig nie. Die algemene genade van God is nie van die mens onttrek nie. Dit verklaar waarom daar nog mooi filosofieë, hoë moraliteit en elemente van waarheid in die verskillende religieë gevind kan word ${ }^{16}$. Die sondeval het egter die mens se vermoë om God soos Hy is te ken en in Gees en waarheid te aanbid en te dien totaal vernietig. Volgens Calvyn is die mens ten opsigte van die kennis van God "blinder as 'n mol" 17 .

Volgens Calvyn kan wysgere in ander religieë soms tlitse van die waarheid omtrent God ontdek soos weerligstrale in die verte, maar in feite bly hulle in die duisternis en kan nie deur rasionele denke by die ware God uitkom nie. Om dié rede kan menslike religieë nie 'n weg tot ware kennis van God wees nie en ook nie 'n weg tot ware gemeenskap met God nie.

Religie is dus niks anders nie as 'n ambivalente menslike verskynsel met elemente van waarheid en valsheid, goed en kwaad, positief en negatief. Die goeie moet toegeskryf word aan die inwerking van die algemene 
genade van God deur sy Gees en die kwade aan die verwoestende uitwerking van die sonde. By uitsondering het begaafde individue in die verskillende religieë wel langs die weg van rasionele denke, mistieke meditasie of deur rituele handelinge tot buitengewone hoogtes gevorder en merkwaardige insigte rondom die kennis van God verkry. Dit is waar van groot profete soos Boeddha, Mohammed, Confusius en andere. Dit bly egter die uitsondering en nie die reël nie. Selfs hierdie gevalle is maar net helder flitse in 'n andersins donker wêreld.

Die helder lig wat hierdie wêreld volkome moes kom verlig en ware verlossende kennis van God moes bring, kon nie langs die weg van religie bereik word nie, maar moes langs die weg van openbaring aan die mens geskenk word. God het genadiglik deur sy herskeppende Woord ingegryp om die verlore sondaar weer tot 'n geloofsverhouding met Hom te roep. Die herstel van die verhouding gaan gepaard met geloof, wedergeboorte en bekering. God se besondere genade en sy besondere self-openbaring vind egter sy hoogtepunt in die inkarnasie van Christus. Deur die Christologiese heilsgebeure word alle menslike religie tot dwaasheid verklaar en as onkunde bekendgestel ( 1 Kor 1:21;2:7; Rom 1:21-22). Nou, in Christus het God se geregtigheid, barmhartigheid en liefde eers werklik sigbaar geword. In die geïnkarneerde Christus leer mense God ken as die God wat betrokke is by die nood van die wêreld en daarom werklik omvattend kan verlos.

Is daar dan geen verlossing moontlik in die religieë nie? God se bedoeling met mense is dat hulle in harmonie met God, met hulle medemens en met die natuur sal leef. Hoewel hierdie verhoudinge grotendeels deur die sonde vernietig is, is dit tog so dat religie ' $n$ bewarende rol kan speel. Mense kan in hulle religieë tog 'n mate van harmonie, geluk en vrede ervaar. Die verwoestende uitwerking van die kwaad kan deur religie getemper word. In hierdie gekwalifıseerde sin, kan religie dus as 'n beperkte verlossingsweg gesien word. Die volmakte verlossing kan egter slegs geskied deur die een Naam wat onder die hemel gegee is waardeur mense verlos moet word (Hand 4:12). Nietemin mag ons die besluit oor die verlossing van mense nie in ons hande probeer neem nie, maar moet dit volledig aan die raadsbeslissing van God oorlaat.

Is daar dan geen kennis van God in die religieë moontlik nie? Dit is duidelik dat daar ' $n$ algemene kennis van God as Skepper afgelei kan word uit die natuur en van God as onderhouer van alle mense uit die geskiedenis en van God as hoogste morele norm van konsensus by alle mense se gewete oor wat reg is en wat verkeerd is. Hierdie algemene kennis van God moet aangevul word deur die besondere kennis van God se heilsbedoelinge met die mens en Sy unieke verlossingsweg vir die mens. 
Bogenoemde stelling kan geïllustreer word aan die hand van drie Skrifgedeeltes naamlik Psalm 19, Handelinge 17:18-31 en Romeine 1:1832 .

In Psalm 19 beskryf verse 2-7 die openbaring in die natuur en verse 8-12 die openbaring deur die Woord (wet) van die Here. Die hemelliggame en by name die son getuig van God se almag en heerlikheid ( $k a b o d$ ). Die naam vir God wat hier gebruik word is $\mathrm{El}$ - die algemene benaming vir die semitiese Opperwese. In die natuur mak God Hom kenbaar as magtige Skepper. Uit die skepping gaan daar 'n stille boodskap uit oor die hele wêreld tot aan die uithoeke van die aarde. Die boodskap kan verstaan word deur alle mense maar lei slegs tot beperkte kennis van God.

Die wet (of woord) van die Here maak God egter op 'n dieper vlak bekend. Die woord bring kennis aangaande Jahwe, die Verlosser en Verbondsgod van Israel. Hy gee die ware lewe (Ps 19:8). Die wet gee geestelike wysheid, bring blydskap en vervulling in die lewe en dui die regte koers aan. Om insig te kry in die ware verlossende kennis van God en om die regte lewe voluit te kon lei is die geopenbaarde wet van Jahwe nodig.

In Handelinge 17:18-31 word Paulus se toespraak op die Areopagus in Athene weergegee. Te midde van die politeïsme van die massas, die materialisme van die Epikuriërs en die panteïsme van die Stoïsyne, sluit Paulus aan by die altaar wat opgerig is "aan 'n onbekende god". Hy sluit aan by die ongedefinieerde bewussyn van 'n almagtige, alwetende en alwerksame Skepper. Hy wil Hom egter nou nader kom bekendstel vir die Atheners. Hy het alle lewe en ook al die nasies geskep. Hy het die mens gemaak om Hom te soek. Tog is hulle soos mense wat in die duister rondtas. $\mathrm{Al}$ is God nie ver van mense af nie, kan $\mathrm{Hy}$ tog nie ten volle geken word nie. Die religieuse bewussyn van mense lei nie na die ware God nie, maar eerder na afgodsdiens (Hand 17:29).

Hierdie "tye van onkunde" het God oorgesien. Tye van onkunde sien op mense wat nog nie die geopenbaarde wil van God leer ken het nie. Met hulle sal God op sy eie wyse handel. Maar nou, nadat God Homself in Christus geopenbaar het, word alle mense opgeroep tot geloof in Hom en tot bekering.

Hy, die opgestane Christus, is immers die persoon deur wie die hele wêreld geoordeel sal word. Nou staan alle menslike religieë onder die oordeel van Christus. Hulle lot word bepaal deur wat hulle met Hom gaan doen.

Ook hier is dit duidelik dat algemene kennis van 'n Skeppergod in werklikheid nog "onkunde" is en dat die ware kennis van God eers 
ontvang word deur geloof in Jesus Christus in wie die volheid van God woon (Kol 2:9).

In Romeine 1:18-32 handel Paulus oor die posisie van die nie-Jode wat nie die wet van God ken nie. Hulle moes in werklikheid kennis van God gehad het, want God het Hom duidelik in die skepping aan alle mense geopenbaar. Hulle moes sy ewige krag en heerlikheid van sy skeppingsdade kon aflei. Tog kan hulle dit nie doen nie as gevolg van die verduistering van hulle verstand. Hulle religieuse pogings en redenasies lei hulle nie tot die ware God nie, maar eerder tot afgodsdiens en morele verval. Omdat hulle in sonde leef, gee God hulle oor aan nog groter sedelike verval. As gevolg van die sonde kan nie-Jode dus nie positief reageer op die algemene openbaring van God nie!

Romeine 2:14-16 toon dat daar tog uitsonderinge op hierdie reël kan wees. Dit is by uitsondering moontlik dat heidene vanself die dinge kan doen wat die wet vereis. Dit gebeur wanneer hulle positief reageer op die algemene openbaring en op die stem van hulle gewetens. Oor hulle dade sal God egter self oordeel en dan ook deur Christus Jesus wat die norm bly.

Romeine 2:17-28 toon dat ook die Jode skuldig is voor God omdat hulle die geskrewe wet van God oortree het en dus negatief op die besondere openbaring reageer het. Jode en heidene is skuldig aan die oortreding van die wet en kan slegs deur die geloof geregverdig word. Vir albei is daar net een verlossingsweg, want daar is net een God. "Hy sal die besnedenes deur die geloof en die onbesnedenes deur dieselfde geloof regverdig verklaar" (Rom 3:29b). Jode en nie-Jode kan dus volkome verlossing vind slegs deur geloof in Jesus Christus.

Wat is dan nou die rol en plek van menslike religieë in verhouding met God se self-openbaring? Ons mag nóg eensydig optimisties nóg eensydig pessimisties oor die religieë van mense oordeel. As ons realisties wil wees, sal ons moet aanvaar dat daar goed en kwaad, reg en verkeerd, verhewe denke en strewes en slefs demoniese elemente in die religieë teenwoordig kan wees. Positief moet ons sê dat God die mens met 'n religieuse bewussyn geskep het en dat religie die mens dus aanspreekbaar maak deur God. Religie maak die mens ten minste 'n soeker na God en skep ruimte vir die werking van God se algemene genade. Dit maak 'n moontlikheid vir die mens om te kon reageer op God se algemene genade in die natuur, in die geskiedenis en in die gewete van die mens. Daar is dus in die religieë 'n religieuse bewussyn en 'n beperkte kennis van God as almagtige en alomteenwoordige Skepper teenwoordig waarby aangesluit kan word in die Christelike verkondiging. 
Negatief moet ons egter sê dat religie as gevolg van die sonde juis ook die weg geword het waardeur mense van die ware God af weggelei word na afgode en na selfverlossing. So gesien is religie niks anders as verdorwe menslike reaksies op God se algemene openbaring nie, net soos Judaïsme en Islam as teïstiese godsdienste niks anders is as onvolkome en gebrekkige reaksies op God se besondere openbaring nie. Om die rede kan religie in die algemeen nie tot verlossende kennis van God lei nie en ook nie tot 'n God-gesentreerde lewe van gehoorsaamheid nie. Met al sy pogings kan die mens nie werklik na God opklim nie, maar God moes na hom toe neerdaal in sy geopenbaarde woord en in die geïnkarneerde Christus. Die weg na verlossende kennis van God word slegs gevind deur die verligtende werking van die Heilige Gees wat die mens in Christus tot wedergeboorte en bekering lei. Die goeie nuus vir alle mense bly steeds dat hulle nie deur vrugtelose selfverlossingspogings gered kan word nie. maar deur die geloof in Christus geregverdig verklaar word. Dit is die goeie nuus wat deur die sending verkondig moet word aan alle mense wat in hulle eie religieë tot selfverlossing mislei word.

Die verhouding van die religieë tot die Christendom kan nie beskryf word as eksklusivisme nie, omdat almal nie by voorbaat uitgesluit kan word van die heil van God nie. Dit kan ook nie aangedui word as inklusivisme nie, omdat almal nie in ' $n$ universele sin gaan deel in die verlossingswerk van Christus nie. Die pluralisme is onaanvaarbaar, omdat dit in stryd is met die belydenis van die kerk deur die eeue dat God homself openbaar het in sy woord en eenmalig in Christus as die Verbondsgod wat sy volk van hulle sonde vryspreek.

Die feit van die saak is dat alle religieë van mense tot dwaasheid verklaar word deur die wysheid van God wat tot openbaring kom in die kruisdood van Christus. Die religieë van mense staan onder die oordeel van die opgestane Christus deur wie alle mense uiteindelik geoordeel sal word. Ook die Christendom as religie word van hierdie oordeel nie uitgesluit nie. Religie as menslike verskynsel kan slegs sy waarde herwin as dit die ruimte word waarbinne God homself deur Sy Woord en Gees openbaar as die Verbondsgod wat met die mens op 'n verlossingsweg gaan deur geloof, wedergeboorte en deur voortdurende bekering. Die waarde van die Christelike kerk lê slegs daarin dat dit van hierdie verlossingsweg mag getuig en opgeroep word om iets daarvan in die lewens van gelowiges te weerspieël. 


\section{NOTAS:}

1 Hierdie standpunt word verdedig deur J Hick, God has many names, Philadelphia 1982.

2 Hierdie indeling word onder andere gebruik deur A Race, Christians and religious pluralism. Patterns in the Christian theology of religions, Maryknoll 1982; G D Costa, Theology and religious pluralism: The challenge of other religions, Oxford 1986; D B Clendenin, Christianity encounters world religions. Many Gods many Lords, Grand Rapids 1995.

3 Hierdie standpunt word gehandhaaf deur $\mathrm{K}$ Barth, "The relevation of God as the abolition of religion”, in: Church Dogmatics, Vol I/II, Edinburgh 1956, 280361 ; vergelyk ook H Kraemer, Religion and the Christian Faith, Philadelphia 1957.

4 Dit is die standpunt van K Rahner, "Christianity and non-Christian Religions", Theological Investigations 17(1966), 39-50. Sedert Vaticanum II is dit ook die offisiële standpunt van die Rooms Katolieke Kerk. Vergelyk D Wright, "Catholic approaches to religions pluralism", in: A D Clarke \& B W Winter, One God one Lord, Grand Rapids 1992.

$5 \quad$ Die standpunt word entoesiasties verdedig deur Hick, $a w, 1982$.

$6 \quad$ Clendenin, $a w, 133$.

7 B A Demarest, "General and special revelation", in: Clarke \& Winter, $a w$, 197.

8 H Vroom, No other Gods. Christian belief in dialogue with Buddhism, Hinduism and Islam, Grand Rapids 1996, 129.

9 Sien die kritiek van Clendenin, $a w, 89-115$.

10 J Hick, "Religious pluralism and the divine: a response to Paul Eddy", Religious Studies $31 / 4$ (1995), 417.

11 D Crafford, "Teologie van die godsdienste", in: P G J Meiring (red), SuidAfrika, land van baie godsdienste, Pretoria 1996, 218.

12 R Otto, The idea of the holy, New York 1967.

$13 \mathrm{~J}$ Wach, Introduction to the history of religions, New York 1988.

14 M Eliade, A history of religious ideas, Chicago 1978.

15 E W Hopkins, Origin and evolution of religion, New York 1969. 
16 J Calvyn, Institutıe 2.2.15 (Vertaling A Sizoo), Delft 1949.

17 Calvyn, $a w, 2.2 .18$. 